\title{
Research on the Current Situation and Countermeasures of Lacking of Employment Integrity of College Students
}

\author{
Chengcheng Yin ${ }^{1}$ Xue $\mathrm{An}^{2, *}$
}

\author{
${ }^{1}$ School of Public Administration, Shandong Technology and Business University, Yantai, Shandong, China \\ ${ }^{2}$ Trauma Department of Orthopedics, 970 Hospital of PLA, Yantai, Shandong, China \\ **Corresponding author. Email: $984884463 @ q q . c o m$
}

\begin{abstract}
This article conducts an in-depth analysis of the current untrustworthy performance of college students in the process of employment. It analyzes the reasons for college students' untrustworthiness in employment from the two dimensions of the college students themselves and the external environment, and proposes targeted improvement strategies.
\end{abstract}

Keywords: employment integrity, college student, countermeasure research

\section{INTRODUCTION}

College students are the future and hope of the country. Their ability to work in good faith is not only related to their own career development and happiness in life, but also related to the economic development and ethos of the whole society. Affected by the Impact of COVID-19, the employment situation is particularly severe this year, and the problem of employment difficulties for college students has attracted increasing attention from the society. Integrity education is an important part of moral education. In the recruitment process, one of the basic conditions for selecting talents is integrity. Lack of employment integrity is not only detrimental to the self-realization of college students, but also affects the corporate image, and is even more detrimental to the development of a good social atmosphere [1]. Therefore, it is an important task for educators to explore the deep-seated reasons behind the lack of employment integrity of college students and seek practical and effective solutions. This is also the ultimate goal of this research.

In 2020 , there will be 8.74 million college graduates nationwide, an increase of 400000 over the same period last year, setting a new record. Affected by the new crown epidemic, many enterprises have been forced to reduce human resources expenditure, the demand for recruitment has declined, and the social unemployment population has increased. In 2020, the overall recruitment demand will drop by $34 \%$, the recruitment demand of fresh graduates will drop by $44 \%$, and the recruitment demand of small and micro enterprises will

*Project: This work is supported by MOE Project of Humanities and Social Sciences (19JDSZ1003). drop by $52 \%$, as summarized in Fig. 1. Compared with the fourth quarter of 2019, the number of college students in the first quarter of 2020 will decrease, but the number of job applicants will increase, so this year's employment situation is particularly grim.

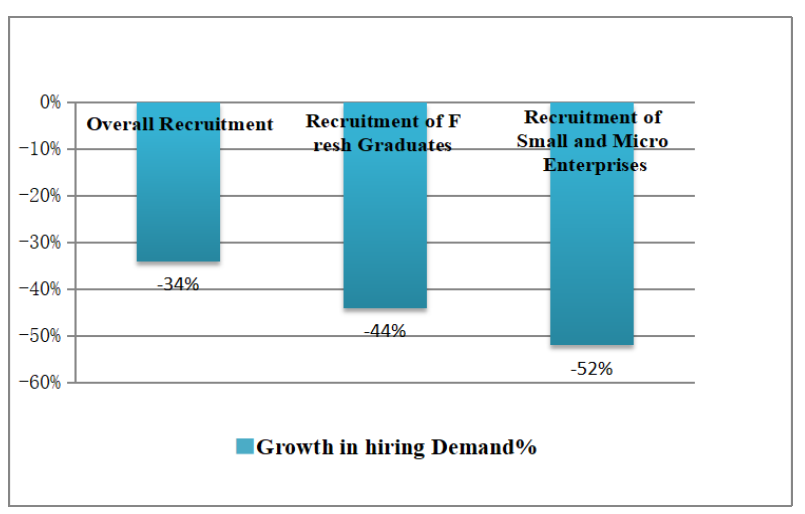

Fig. 1. Recuritment demand in the Chinese market in 2020

\section{THE PERFORMANCE OF COLLEGE STUDENTS' LACK OF EMPLOYMENT INTEGRITY}

\section{A. During the job hunting process, False job search materials, lying in the interview process}

The job application materials are the basis for the employer to identify graduates, and mainly include job application resumes, honors and skills certificates. Some graduates take measures to improve their chances of passing the interview, such as beautifying their job resumes, falsifying academic transcripts and honor certificates, filling in false internship work experience and cadre experience, etc. The interview is an important part of the employer's inspection of graduates. The performance of graduates in the interview process has a 
critical impact on the results of the employment. Interview is an interactive communication process. The employer will set up different scenarios to comprehensively understand the graduates. Similarly, the graduates will show themselves in all aspects through various methods. However, interviews are characterized by many interviewers and limited time. Therefore, employers can only make preliminary judgments on job applicants in a short time. In order to get a perfect impression, some graduates fabricated and lied about some issues, such as falsifying personal grades and acknowledging others' credit to suit the preferences of employers.

\section{B. Random breach of contract after signing the contract, lack of contract spirit}

In order to accumulate job-hunting experience and reduce the uncertainty of employment, many graduates will apply for several units at the same time during the employment process. However, some students, in the absence of understanding of the employer, as long as there is an olive branch, they immediately sign an employment agreement with the employer. Once they have a better choice, they will break the contract with the previous unit. This behavior increases the recruitment cost of employers and damages the image of graduates and schools [2].

\section{ATTRIBUTION ANALYSIS OF THE LACK OF EMPLOYMENT INTEGRITY OF COLLEGE GRADUATES}

The reasons for the lack of employment integrity of college graduates can be divided into external factors and their own factors. External factors mainly include three dimensions: society, colleges, and families.

\section{A. From the perspective of its own reasons, college students have a weak sense of employment integrity}

Some graduates have insufficient knowledge of themselves and society, and their employment goals are unclear or unrealistic. Faced with fierce competition and huge employment pressure, many college students are not fully prepared ideologically, psychologically, and abilities. The originally very weak sense of integrity is affected. In order to satisfy their employment ideals and obtain better employment Opportunities, to adopt excessive packaging or even false packaging and other behaviors such as lack of employment integrity [3].

\section{B. From an external perspective, society, colleges, and} families play a comprehensive role

In terms of society, the phenomenon or reports of lack of credit and fraud, have a certain impact on the undefined values of college students. In colleges and universities, the teaching mode that emphasizes theory over practice, students' interest is not high, and the concept of honesty is only taught as knowledge, not rooted in the hearts of students, and transformed into practical actions, resulting in poor integrity education. In terms of families, some parents one-sidedly emphasize achievement and ignore the importance of moral education, especially integrity education. Parents' high expectations for their children also indirectly lead to some graduates choosing to resort to fraud to achieve their employment goals.

\section{COUNTERMEASURES FOR THE LACK OF EMPLOYMENT INTEGRITY OF COLLEGE GRADUATES}

Solving the problem of college students' employment credibility is a systematic project, which requires society, colleges, families and college students to form a joint force to build a synergistic employment credibility system for college students.

\section{A. The government must actively play its role in creating a social environment for honest employment}

The government should base its role as a service provider and supervisor in the employment integrity of college students. First of all, it is necessary to transform the economic development mode, provide more jobs, meet the employment needs of college students, and ease the employment pressure of college students. Second, optimize service functions. On the one hand, we will strengthen employment guidance, improve laws and regulations, and provide institutional guarantees for college students to achieve fair employment [4]. On the other hand, with the help of new media platforms, we will set a good example of good faith, strengthen the publicity and education of good faith education, and create a good atmosphere of good faith in the whole society. Furthermore, it is necessary to establish and increase punishment for untrustworthy employment, establish a list of untrustworthy employment, and gradually form a good integrity ecosystem.

\section{B. Families should attach importance to honesty education, pay attention to precepts and deeds}

Family education has a profound impact on the growth of students. Responsible family education will benefit children throughout their lives. First, we must strictly self-discipline and lead by example. As a child's enlightenment teacher, parents are the best teaching materials for their children. Their behavior, words and deeds play a vital role in the growth and development of their children. Parents must create a good family style so that their children can become talents in an excellent and honest family. Second, it is necessary to strengthen the integrity and moral education of children, and in the critical period of children's growth, we must take a good direction and promptly correct 
children's dishonest behavior [5]. Third, it is necessary to strengthen communication with the school, through the joint efforts of home and school to cultivate children's integrity, and shape their healthy personality.

\section{Colleges and universities should enrich the content of integrity education and innovate the form of integrity education}

Colleges and universities should enrich the content of honesty education, optimize the form of honesty education through educational management, public opinion guidance, and student activities, and root a scientific honesty cognition system among students. It is necessary to help students understand the employment policy and make a good career plan at the beginning of students' enrollment, and to organize a series of education activities on integrity education in addition to traditional lectures. Such as the development of integrity examination education, integrity essays, theme speech contests, theme class meetings, etc; organizing students to visit and study outside the school, and launching integrity practice activities. Especially before students are about to graduate, it is necessary to strengthen employment guidance and employment integrity education. It is necessary to pay attention to the transfer of professional knowledge and skills, but also to integrate the education of employment-related laws and policies throughout daily education activities and strengthen the practice of integrity education. Enable students to achieve unity of knowledge and action [6].

\section{College students must be strict with themselves and strengthen their sense of integrity}

Social environment creation, school and family education are all external factors, and external factors can only play a role through internal factors. On the one hand, college students should correct their learning attitudes and make full use of their time at university to improve their professional standards. They should not only learn solid professional knowledge and abilities, but also improve their oral expression skills, communication and cooperation skills, and actively participate in club activities and social practices to enhance Employment competitiveness. On the other hand, we must establish correct values, establish a sense of integrity, strictly demand ourselves, and strengthen our sense of responsibility and self-discipline.

\section{CONCLUSION}

Solving the problem of lack of integrity in employment of college students is difficult to achieve with the efforts of one party alone, and requires the joint efforts of the whole society. Establish a sound market integrity system and form a good integrity atmosphere. Strengthening the integrity education of college students is an urgent task to solve the lack of integrity of college students in employment. While cultivating the integrity of college students, colleges and universities should strengthen employment education for college students, help them clarify their employment goals and make career plans. Only with a clear employment direction can the blindness of employment selection be reduced. At the same time, it is necessary to actively create a good social honesty environment, so that college students will be subtly affected in an atmosphere of honesty, and form a good quality of honesty and trustworthiness.

\section{References}

[1] Zhang Lu.Research on the Lack of Honesty and Credit of College Students in Employment.Education Teaching Forum 2019:233-234

[2] Song Dawei. Research on the Honest Employment of College Graduates. Teaching and Educating(Higher Education Forum) 2018:7-9

[3] Liu Min.Research on the Importance of Honesty Education for College Students in Employment Environment. Labor Security World 2018:42

[4] Shi Yi,Yang Dexiang.Unbalanced Employment Credit of Contemporary College Students and Countermeasures.Journal of Yangtze University(Social Science Edition) 2018,41:117121.

[5] Zhou Xiandong.Research on Honesty Education of College Students from the Perspective of Employment.Journal of Harbin Vocational and Technical College 2017:75-77.

[6] Xing Fengxia. On the Causes and Countermeasures of College Students' Employment Integrity.Legal System and Society 2017:173-174. 